\title{
Pain intensity in patients with juvenile idiopathic arthritis with respect to the level of their activity and disease acceptance
}

\author{
Natężenie bólu u chorych na młodzieńcze idiopatyczne zapalenie stawów \\ a poziom aktywności i akceptacji choroby
}

\author{
Grażyna Cepuch ${ }^{1}$, Lucyna Tomaszek ${ }^{2}$, Małgorzata Trybek-Bronowicz ${ }^{3}$ \\ ${ }^{1}$ Faculty of Health Sciences, Jagiellonian University Medical College, Krakow \\ ${ }^{2}$ Andrzej Frycz-Modrzewski Krakow University, Faculty of Medical Sciences, Krakow \\ ${ }^{3}$ Graduate of Faculty of Health Sciences, Jagiellonian University Medical College, Krakow
}

Key words: pain, acceptance, activity, juvenile idiopathic arthritis.

Słowa kluczowe: ból, akceptacja, aktywność, młodzieńcze idiopatyczne zapalenie stawów.

\section{Sum mary}

Objectives: Being diagnosed with a chronic disease, such as juvenile idiopathic arthritis (JIA), may adversely affect the activity of a young person. Additionally, the pain associated with the disease may cause difficulty accepting it. The aim was to assess the intensity of pain as well as the degree of activity and acceptance of the disease in young people aged 14-18 years with JIA.

Material and methods: The study group consisted of youth of both genders suffering from JIA aged 14-18 years during remission of the disease. The study included 50 people and used the following: numerical rating scale (NRS 0-10), Cantril ladder, activity scale of own authorship (grouped items of the questionnaire form subscales of: tiredness, physical activity, social and intellectual activity) and Acceptance of Illness Scale (AIS). Statistical analysis included the following tests: Mann-Whitney $U$ test, Wilcoxon's, $\chi^{2}$ test, Fisher's, and Spearman rank correlation. The statistical significance level was set as $p$ value below 0.05 .

Results: The majority of the respondents observed currently do not feel pain or feel pain of low intensity. The young people are physically, psychologically and socially active. The majority of patients accept their illness. The patients who suffer from pain on the NRS scale within 4-7 points do not adapt to living with the disease as do patients without pain or experiencing pain of low intensity. There was a strong correlation between acceptance of the disease at the time of the study determined by the Cantril ladder and AIS.

Conclusions: 1 . The pain suffered by patients with juvenile idiopathic arthritis (JIA) has undoubtedly a negative impact on their activity and acceptance of the disease. 2 . It seems to be crucial to recognize pain as a significant determinant of acceptance of the disease.

\section{Streszczenie}

Cel pracy: Rozpoznanie choroby przewlekłej, jaką jest młodzieńcze idiopatyczne zapalenie stawów (MIZS), wpływa negatywnie na aktywność młodego człowieka. Dodatkowo ból towarzyszący chorobie może też w znaczny sposób powodować trudności z jej zaakceptowaniem. Celem pracy była ocena stopnia natężenia bólu oraz stopnia aktywności i akceptacji choroby przez młodzież w wieku 14-18 lat z MIZS.

Materiał i metody: Grupę badawczą stanowiła młodzież obojga płci w wieku 14-18 lat z MIZS w okresie remisji. Badaniami objęto 50 osób. W badaniu zastosowano: skalę numeryczną (NRS 0-10), drabinę Cantila, skalę aktywności własnego autorstwa (pogrupowane pozycje kwestionariusza tworzą podskale: zmęczenia, aktywności fizycznej, aktywności społecznej, aktywności intelektualnej) oraz skalę akceptacji choroby (AIS). Analizę statystyczną przeprowadzono za pomocą testów: Manna-Whitneya, Wilcoxona, $\chi^{2}$, Fishera, korelacji rang Spearmana. Do obliczeń przyjęto istotność statystyczną $p<0,05$.

Wyniki: Większość badanych osób nie odczuwa obecnie bólu lub odczuwa go w niewielkim stopniu. Młodzież wykazuje dużą aktywność w sferze fizycznej, psychicznej i społecznej. Przeważająca część pacjentów akceptuje swoją chorobę. Chorzy odczuwający ból określany w skali NRS na 4-7 pkt gorzej adaptują się do życia z chorobą w porównaniu z pacjentami bez dolegliwości bólowych albo odczuwających ból o słabym nasileniu. Stwierdzono wysoką korelację pomiędzy akceptacją choroby w chwili badania określoną za pomocą drabiny Cantrila i skali AIS.

Wnioski: 1. Ból odczuwany przez chorych na MIZS ma niewątpliwie negatywny wpływ na poziom ich aktywności oraz stopień akceptacji choroby. 2. Wydaje się kluczowe uznanie bólu jako znaczącego wykładnika akceptacji choroby.

Address for correspondence:

Grażyna Cepuch, MD, PhD, Faculty of Health Sciences, Jagiellonian University Medical College, Kopernika 25, 31-500 Krakow,

e-mail: grazyna.cepuch@uj.edu.pl

Submitted: 20.08 .2014 


\section{Introduction}

Juvenile idiopathic arthritis (JIA) is one of the most common, chronic, immuno-inflammatory arthropathies of developmental age [1-6]. Juvenile idiopathic arthritis is associated with increasing disability and pain resulting mainly from the nature of the disease and its consequences. As a chronic disease, JIA negatively affects many areas of life, forcing patients to modify their life plans [7, 8].

Adaptation and acceptance of the disease are of particular importance in the treatment of an adolescent patient. Adaptation of the disease depends largely on what is reflected in the cognitive psychology of the patient. What they know about the disease, how they perceive it, understand it and evaluate it, allows them to create a subjective image of the condition. This image affects the experiences and the behavior, intensifying or weakening the negative emotions, as well as strengthening or weakening the motivation to overcome difficulties in the treatment process [9].

Both biopsychological experiences, that is mental and organic disease symptoms (especially pain), and social experience, including public opinion on this disease, play an important role in creation of the image of the disease [9].

It is also recognized that the process of adaptation to the illness affects self-esteem, which is created by two main mechanisms - the belief in the value of self autonomy and assessing oneself in relation to others. During adolescence, self-esteem is significantly reduced, and together with the simultaneous impact of stress associated with malaise, pain, and limitations resulting from illness, all these factors may influence emotional states and hinder adaptation to the disease [10-13]. The higher the acceptance level, the better the adaptation and lower discomfort resulting from the disease. Therefore, stress caused by illness is less intense, and self-esteem is enhanced, which is an extremely important factor for a teenager. The illness adaptation process is treated as a general re-adaptation to the new situation [14]. The search for meaning and a positive reaction to new developments, including reinterpretation of the assessment of one's own life, efforts to gain control over the situation and a sense of personal influence to regain self-esteem, constitute an important phase of adaptation to the disease $[14,15]$. Only those patients who treat the disease as a challenge worth the commitment can find meaning and significance in their suffering, which enables actions aiming to regain health. Lack of these conditions causes serious adaptive difficulties [14]. Not only the teenager, but also their parents, must get used to the new situation. Going through the process of adaptation, in both social-emotional and cognitive aspects, allows parents and their children to provide support [16, 17], as well as to receive it.

\section{Aim of the study}

The aim of this study was to evaluate the relationship between the level of pain experienced by patients with IIA and their degree of disease acceptance and activity.

\section{Material and methods}

The study was conducted at the Children's Specialist Hospital św. Ludwika in Krakow and Podkarpacki Hospital Jana Pawła II in Krosno, with the approval of the hospitals' management. The study group consisted of 50 adolescents suffering from JIA, of both sexes, aged 14-18 years, during the dormant stage of the acute symptoms of the disease. Patients were informed about the purpose of the study and gave voluntary consent to participate in it. During the study the principles of ethics and of personal data protection were respected. Patients with various additional illnesses were excluded from participation in the study.

All patients were studied in terms of severity of pain, the degree of activity during the disease and its acceptance.

The severity of pain was assessed using a numerical rating scale (NRS), defining pain from 0 to 10 points, where 0 represents no pain and 10 represents the worst pain that one can imagine [18].

A patient's degree of activity was determined using the Scale Activity (SA) by Cepuch [19]. The person tested described themselves using a questionnaire by selecting one of the 5 possible answers to the statements, where 1 is "definitely not", 2 is "probably not", 3 is "don't know", 4 is "probably yes", and 5 is "definitely yes". The overall result of the questionnaire is the sum of points of all 13 items (minimum 13 points to maximum 65 points). Grouped items of the questionnaire form subscales of: tiredness, physical activity, social and intellectual activity.

Two measurement tools were used to evaluate the acceptance of the disease: the Acceptance of Illness Scale (AIS) in Juczyński's adaptation [20] and the Cantril ladder [21, 22].

The Cantril ladder is a graphic tool presented in the form of a ladder. "O" was placed at the bottom of the ladder with the comment "I do not accept my illness at all", followed by successive numbers towards the top of the ladder, with number "10" representing the statement "I fully accept my illness". On one of the ladders respondents were asked to tick the numerical value corresponding to their current feeling, and on the other patients forecasted as they would expect to perceive their disease after a period of 6 months.

AIS includes 8 statements that describe the negative consequences of the disease for health, such as recog- 
nizing the limitations imposed by the disease, lack of self-sufficiency, a sense of dependence on others and low self-esteem. For each of the statements, respondents could indicate a numerical value in the range from 1 to 5 . The total number of points was a general measure of the degree of disease acceptance, ranging from 8 to 40 points.

Statistical analysis was performed based on procedures available in Statistica 10. Quantitative variables were presented using median and upper and lower quartile (deviating from the norm). Normality of the system was checked using the Shapiro-Wilk test. The values of the qualitative variable were represented by the absolute values and percentage. To compare quantitative variables between independent groups the Mann-Whitney test was used, while in dependent groups the Wilcoxon signed-rank test was used. Qualitative variables were compared using the $\chi^{2}$ test or Fisher's test (independent groups). The relationship between variables was determined by Spearman's rank correlation coef- ficient. For the purposes of this calculation, statistical significance at $p<0.05$ was established.

\section{Results}

Altogether, 50 patients aged 14-18 years suffering from JIA were analyzed during a minimum 6-month period. The majority of patients were girls (58\%).

The results of assessment of pain severity experienced by hospitalized patients using the NRS are presented in Fig. 1; they formed the basis for allocation of the study population into two groups: group 1 ( $n=32$; NRS $=0-3$ points) and group $2(n=18 ;$ NRS $=4-7$ points). Demographic characteristics of the two groups are presented in Table I.

Assessment of physical, social, and intellectual activity in patients with JIA using the SA scale showed significant differences between the groups (Table II). Patients who experienced pain at the time of the study within 4-7 points (group 2) claimed that pain definitely makes

Table I. Demographic characteristics of studied groups

\begin{tabular}{|c|c|c|c|c|c|c|c|}
\hline \multicolumn{2}{|c|}{ Parameter } & \multicolumn{2}{|c|}{$\begin{array}{l}\text { Group I } \\
(N=32)\end{array}$} & \multicolumn{2}{|c|}{$\begin{array}{l}\text { Group II } \\
(N=18)\end{array}$} & \multirow[t]{2}{*}{$\begin{array}{c}\text { Statistical } \\
\text { test }\end{array}$} & \multirow[t]{2}{*}{$p$} \\
\hline & & $n$ & $\%$ & $n$ & $\%$ & & \\
\hline \multirow[t]{5}{*}{ Age (years) } & 14 & 8 & 25 & 7 & 38.9 & \multirow[t]{5}{*}{ Fisher } & \multirow[t]{5}{*}{0.253} \\
\hline & 15 & 6 & 18.8 & 3 & 16.7 & & \\
\hline & 16 & 5 & 15.6 & 3 & 16.7 & & \\
\hline & 17 & 6 & 18.8 & 5 & 27.8 & & \\
\hline & 18 & 7 & 21.9 & 0 & 0.0 & & \\
\hline \multirow[t]{2}{*}{ Gender } & female & 18 & 56.3 & 11 & 61.1 & \multirow[t]{2}{*}{$\chi^{2}$} & \multirow[t]{2}{*}{0.738} \\
\hline & male & 14 & 43.8 & 7 & 38.9 & & \\
\hline
\end{tabular}

Table II. Basic characteristics of the degree of activity in illness assessed with the Activity Scale (according to Cepuch)

\begin{tabular}{|c|c|c|c|c|c|c|}
\hline \multirow[t]{2}{*}{$\begin{array}{l}\text { Parameter- } \\
\text { subscale }\end{array}$} & \multicolumn{2}{|c|}{$\begin{array}{l}\text { Group I } \\
(N=32)\end{array}$} & \multicolumn{2}{|c|}{$\begin{array}{l}\text { Group II } \\
(N=18)\end{array}$} & \multirow[t]{2}{*}{ Statistical test } & \multirow[t]{2}{*}{$p$} \\
\hline & $M$ & Q25/Q75 & $M$ & Q25/Q75 & & \\
\hline $\begin{array}{l}\text { Fatigue } \\
\text { ( } T=2-10 \text { points })\end{array}$ & 2.5 & $2-4$ & 8 & $8-9$ & & 0.000 \\
\hline $\begin{array}{l}\text { Limited physical activity } \\
(T=2-10 \text { points) }\end{array}$ & 4 & $2-4.5$ & 9 & $6-9$ & Mann-Whitney & 0.000 \\
\hline $\begin{array}{l}\text { Limited social activity } \\
\text { ( } T=4-20 \text { points })\end{array}$ & 4.4 & $4-7.5$ & 10 & $8-15$ & & 0.000 \\
\hline $\begin{array}{l}\text { Limited intellectual activity } \\
\text { ( } T=5-25 \text { points) }\end{array}$ & 8 & $5-10$ & 17 & $15-19$ & & 0.000 \\
\hline
\end{tabular}

M-median; upper and lower quartile Q25-Q75

$T$-total points in subsequent subscales; minimum and maximum 
them tired and weary (36\% vs. $0 \%$ ), or affects these feelings (58.5\% vs. $6 \%$ ). Pain restricts the ability to perform basic actions such as walking up and down the stairs (definitely yes: $56 \%$ vs. $3 \%$; probably yes: $11 \%$ vs. $13 \%$ ), washing, dressing up and eating (definitely yes: $6 \%$ vs. 0\%, probably yes: $72 \%$ vs. $3 \%$ ).

To a lesser extent, pain contributes to the avoidance of meetings with family and friends, and reluctance to make new acquaintances (definitely yes: $9 \%$ vs. $0 \%$; probably yes: $23.7 \%$ vs. $0 \%$ ). The negative effects of pain also affect the sphere of intellectual life. Patients often have

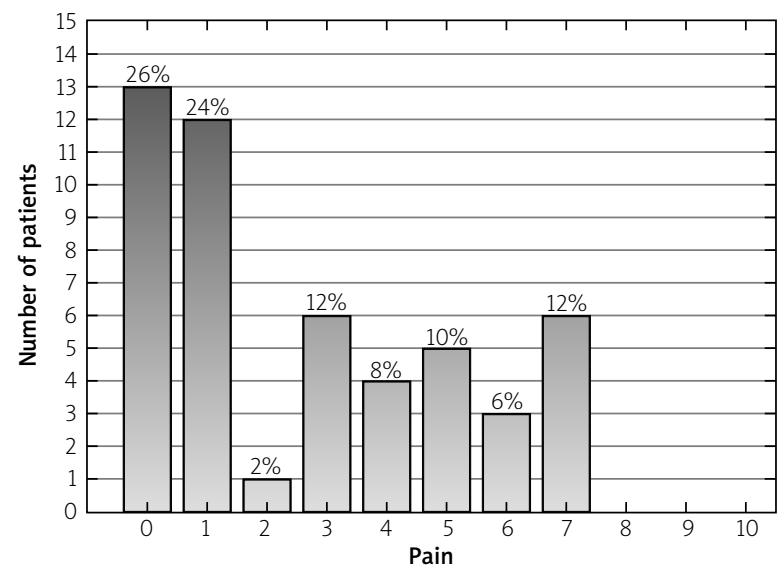

Fig. 1. Distribution of pain intensity measured by the numerical rating scale (NRS 0-10 points; $n=50)$.

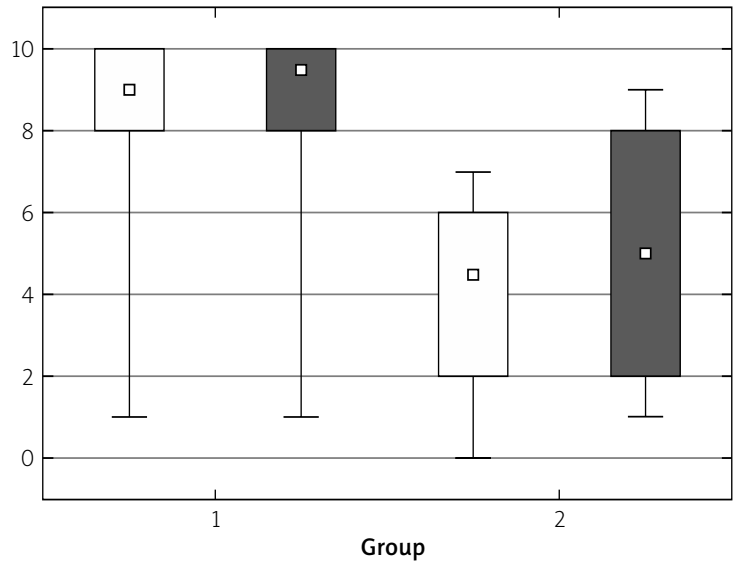

$$
\begin{array}{lc}
\square \text { Median } & \square \text { Acceptance of illness at the of examination; } \\
\square 25-75 \% & \text { group 1 vs. group 2; } p=0.000 \text { (Mann-Whitney test) } \\
\square \text { Acceptance of illness after six months } \\
\text { IMin-Max } & \text { group 2: 回 vs. 四; } p=0.003 \text { (Wilcoxon test) }
\end{array}
$$

Fig. 2. Cantril's ladder scale - acceptance of illness at the time of examination and after six months ( $0=$ I do not accept my illness at all; 10 $=$ I fully accept my illness). trouble with concentration and memory (definitely yes: $17 \%$ vs. $0 \%$; probably yes: $78 \%$ vs. $13 \%$ ), learning (definitely yes: $17 \%$ vs. $0 \%$; probably yes: $67 \%$ vs. $6 \%$ ).

While assessing the relation between the level of pain experienced by the patients and the degree of the disease acceptance presented in the Cantril ladder (Fig. 2), it was noted that patients who did not feel pain or reported it as weak (1-3 points) accepted their disease better than patients experiencing pain from 4 to 7 points ( $p=0.000$, Mann-Whitney $U$ test). Patients declaring the sensation of pain above 3 points also expressed the belief that in six months their acceptance of the disease would be higher than at the time of the study $(p=0.003$, Wilcoxon test).

Analysis of results of disease acceptance obtained through the AIS scale (Fig. 3) confirmed that patients who suffer from pain within 4-7 points do not adapt to living with the disease as do patients without pain or experiencing pain of low intensity. There was a strong correlation between the level of acceptance of the disease determined by the Cantril ladder and the one determined by the AIS (Fig. 4).

\section{Discussion}

Negative effects of JIA may be particularly burdensome for young people who compare themselves with healthy peers. Observing the difference, they may find it difficult to accept their illness and the limitations that derive from it.

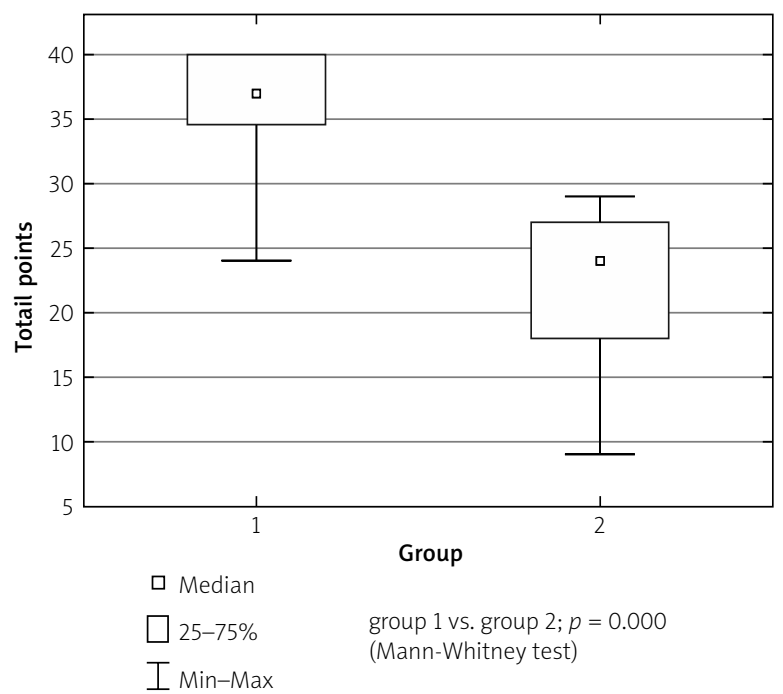

Fig. 3. Acceptance of Illness Scale (AIS; possible scores 8-40 points; total number of points obtained by patients describes degree of acceptance of illness at the moment of examination). 
Among the patients tested, most of them did not feel pain or its intensity was low. This is unexpected considering the fact that pain from the musculoskeletal system caused by ongoing inflammation is one of the main typical symptoms of JIA. Such low levels of pain in patients may have resulted from a dormant period of the symptoms, effective treatment, including analgesic treatment, or the superimposition of all those factors. The study conducted by Cepuch et al. [23], which analyzed the source of pain in rheumatic diseases, showed that the major source was the disease itself. The average pain intensity reached 6 points on the NRS and was higher than in patients with cancer [24].

Assessment of tiredness conducted in the study using the Activity Scale showed that more than half of the respondents claimed that the pain they were currently experiencing was not the source of tiredness. Many patients, however, pointed to the pain as a trigger. Studies that used the same scale among adolescents with cancer and adolescents with JIA indicated a close relation between pain and tiredness. However, the above studies found higher levels of pain intensity [25]. Thus, it seems reasonable to recognize pain, tiredness and weariness as significant moderators in the process of disease adaptation.

Our findings indicate a relation between the degree of pain intensity and physical, mental and social activity. The disease, when not accompanied by pain, does not hinder young people's daily activities or desire for social life. Young people who experience pain of a higher level are less active, which is also confirmed in studies of other authors $[23,26]$.

Based on the analysis of our findings, it can be concluded that adolescents with low levels of pain ( $<3 / 10$ pts) show a positive attitude towards their disease in both subjective and objective opinion, which is reflected in almost complete acceptance of the illness at the time of the study (median 9) and in the following six months (median 9.5). This shows that young people have a positive attitude towards their disease [11], despite the awareness that JIA is a chronic condition and requires long treatment, follow-up visits, and often modification of life, such as school choice or profession. However, people who experience a higher level of pain (> 3/10 points) accept their illness to a lesser extent (median 4.5), with the simultaneous conviction that in six months their acceptance of the disease will be higher than at the time of the study (median 5). One can assume that the foundation of such a declaration is mainly hope for health improvement, and therefore milder and painless JIA, which seems to allow the respondents to come to terms with their health situation.

Research on acceptance of the disease among girls with IIA performed by Kosmala et al. [27] showed that the majority of respondents did not perceive the disease as a situation that impeded the pursuit of their life plans.

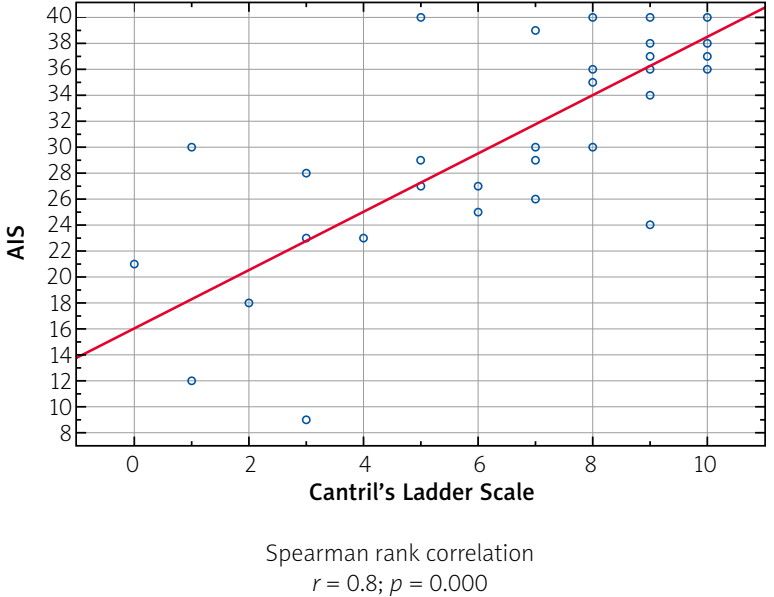

Fig. 4. Correlation between scores assessed with Cantril's ladder scale (0-10 points) and Acceptance of Illness Scale (AIS; possible scores 8-40 points).

The above analysis shows that despite being a chronic disease, with all its consequences, JIA is not a factor determining a reduction of the patient's activity in multiple areas. It can also be recognized that teenagers adapt well to the disease and accept the situation. The majority of young patients are able to enjoy their lives in many fields, provided however that their treatment is sufficiently effective and minimizes the intensity of pain [28-30].

\section{Conclusions}

Pain intensity influences the level of physical, psychological and social activity as well as the degree of disease acceptance.

It seems to be crucial to recognize pain as a significant factor of disease acceptance.

The authors declare no conflict of interest.

\section{References}

1. Cimaz R, Moretti D, Pagnini L, et el. What do cytokine profiles tell us about subsets of juvenile idiopathic arthritis? Curr Rheumatol Rep 2012; 14: 150-154.

2. Żuber Z. Młodzieńcze idiopatyczne zapalenie stawów. Pediatr Dypl 2012; 16: 23-32.

3. Cassidy JT, Petty RE. Juvenile idiopathic arthritis. In: Textbook of pediatric rheumatology. Cassidy JT, Petty RE (eds.). WB Saunders, Philadelphia 2005: 291-303.

4. Hinze $\mathrm{CH}$, Fall $\mathrm{N}$, Thornton $\mathrm{S}$, et al. Immature cell populations and an erythropoiesis gene-expression signature in systemic juvenile idiopathic arthritis: implications for pathogenesis. Arthritis Res Ther 2010; 12: R123. 
5. Brennan FM, McInnes IB. Evidence that cytokines play a role in rheumatoid arthritis. J Clin Invest 2008; 118: 3537-3545.

6. Jelusic M, Lukic IK, Tambic-Bukovac L, et al. Interluekin 18 as mediator of systemic juvenile idiopatic arthritis. Clin Rheumatol 2007; 26: 1332-1334.

7. Banasiak B, Smolewska E, Lipińska J, et al. Proces adaptacji do choroby przewlekłej u dzieci i młodzieży z młodzieńczym idiopatycznym zapaleniem stawów na podstawie 2-letniej obserwacji. Przegl Pediatr 2009; 39: 172-177.

8. Heszen I. Kliniczna psychologia zdrowia. In: Psychologia kliniczna. Sęk H (red.). Wydawnictwo Naukowe PWN, Warszawa 2005: 230-235.

9. Maziarz A. Dziecko przewlekle chore. Opieka i wsparcie. Wydawnictwo Akademickie Żak, Warszawa 2004.

10. Spaczyńska N, Strzelecki W, Orzeszko-Spaczyńska A. Zapalne układowe choroby tkanki łącznej a psychika chorego dziecka. Pediatr Prakt 2006; 14: 9-14.

11. Cepuch G, Dobrogowski J, Wordliczek J. The perception of purpose and sense of life and satisfaction in young people with cancer and rheumatic disease. Adv Palliative Med 2007; 6: 3-12.

12. Vaeroy H, Tanum L, Bruaset $\mathrm{H}$, et al. Symptoms of depression and anxiety in functionally disabled rheumatic pain patients. Nordic J Psychiatry 2005; 59: 109-113.

13. Suurmeijer TH, van Sonderen FLP, Krol B, et al. The relationship between personality, supportive transactions and support satisfaction, and mental health of patients with early Rheumatoid Arthritis. Soc Ind Res 2005; 73: 179-197.

14. Niedzielski A, Humeniuk E, Błaziak P, Fedoruk D. Stopień akceptacji choroby w wybranych chorobach przewlekłych. Wiad Lek 2007; 60: 224-227.

15. Taylor SE. Adjustment to threating events: a theory of cognitive adaptation. Am Psychol 1983; 11: 1161-1173.

16. Dobrucka-Janeczek I, Rutkowska-Sak L. Osobowość i przystosowanie dzieci chorych na przewlekłe choroby reumatyczne. Reumatologia 2012; 50: 211-218.

17. Żuk B, Księżopolska-Orłowska K. Adaptacja rodziców do opieki nad dzieckiem z młodzieńczym idiopatycznym zapaleniem stawów. Reumatologia 2010; 48: 165-170.

18. Misiołek H, Mayzner-Zawadzka E, Dobrogowski J, Wordliczek J. Zalecenia 2011 postępowania w bólu ostrym i pooperacyjnym. Ból 2011; 12: 9-33.

19. Cepuch G. Wordliczek J. Natężenie bólu a stan emocjonalny i aktywność młodocianych z chorobą nowotworową. Przegl Lek 2009; 66: 181-186.

20. Juczyński Z. Narzędzia pomiaru w promocji i psychologii zdrowia. Pracownia Testów Psychologicznych, Warszawa 2009.

21. Czapiński J. Psychologia szczęścia. Przegląd badań i zarys teorii cebulowej. Wydział Psychologii Uniwersytetu Warszawskiego. Warszawa 1992.

22. Cantril H. The Patterns of Human Concerns. Rutgers University Press. New Brunswick, NY, USA 1965.

23. Cepuch G, Perek M. Ból a aktywność i zmęczenie u młodzieży hospitalizowanej z powodu choroby reumatycznej. W: Problemy osób niepełnosprawnych, Turowski K, Paluszkiewicz P, Spisacka S (red.). Biała Podlaska 2007: 187-193.

24. Cepuch G, Wordliczek J, Golec A. Wybrane skale do badania natężenia bólu u młodzieży - ocena ich przydatności. Pol Med Paliatywna 2006; 5: 108-113.
25. Cepuch G, Wordliczek J. Ból a aktywność i zmęczenie u młodocianych hospitalizowanych z powodu choroby nowotworowej i reumatycznej. Folia Med Cracov 2006; 1-4: 3-20.

26. Pawelczyk B, Małecka E, Bornakowska-Zabel E. Pilotażowe badania jakości życia dzieci z młodzieńczym przewlekłym zapaleniem stawów - postacią wielostawową i kilkustawową. Pediatr Prakt 1998; 1: 33-37.

27. Kosmala E, Korobowicz A, Olesińska E. Psychologiczne aspekty funkcjonowania dziewcząt z młodzieńczym idiopatycznym zapaleniem stawów. Przegl Pediatr 2004; 34: 26-31.

28. Lal SD, McDonagh J, Baildam E, et al. Agreement between proxy and adolescent assessment of disability, pain, and well-being in juvenile idiopathic arthritis. J Pediatr 2011; 158: 207-212.

29. Ostile IL, Johansson I, Aasland A, et al. Self-rated physical and psychosocial health in a cohort of young adults with juvenile idiopathic arthritis. Scand J Rheumatol 2010; 39: 318-325.

30. Kwissa-Gajewska Z, Olesińska M, Tomkiewicz A. Optymizm, strategie radzenia sobie $z$ bólem $\mathrm{i}$ jego nasilenie u pacjentek z reumatoidalnym zapaleniem stawów. Reumatologia 2014; 52: $166-171$ 